Historic, archived document

Do not assume content reflects current scientific knowledge, policies, or practices. 



\section{BIRDS PROTECTED BY FEDERAL LAW}

Authority: Migratory Bird Treaty Act (Act of July 3, 1918, 40 Stat. 755 as amended by Act of June 20, 1936,49 Stat $1555-16$ U.S.C. $703-711$ ) ; Bald Eagle Act (Act of June 8, 1940, 54 Stat. 250; 16 U.S.C. 668 as amended by Act of June
25, 1959, 73 Stat. 143)

Compiled May 1961

Branch of Management and Enforcement

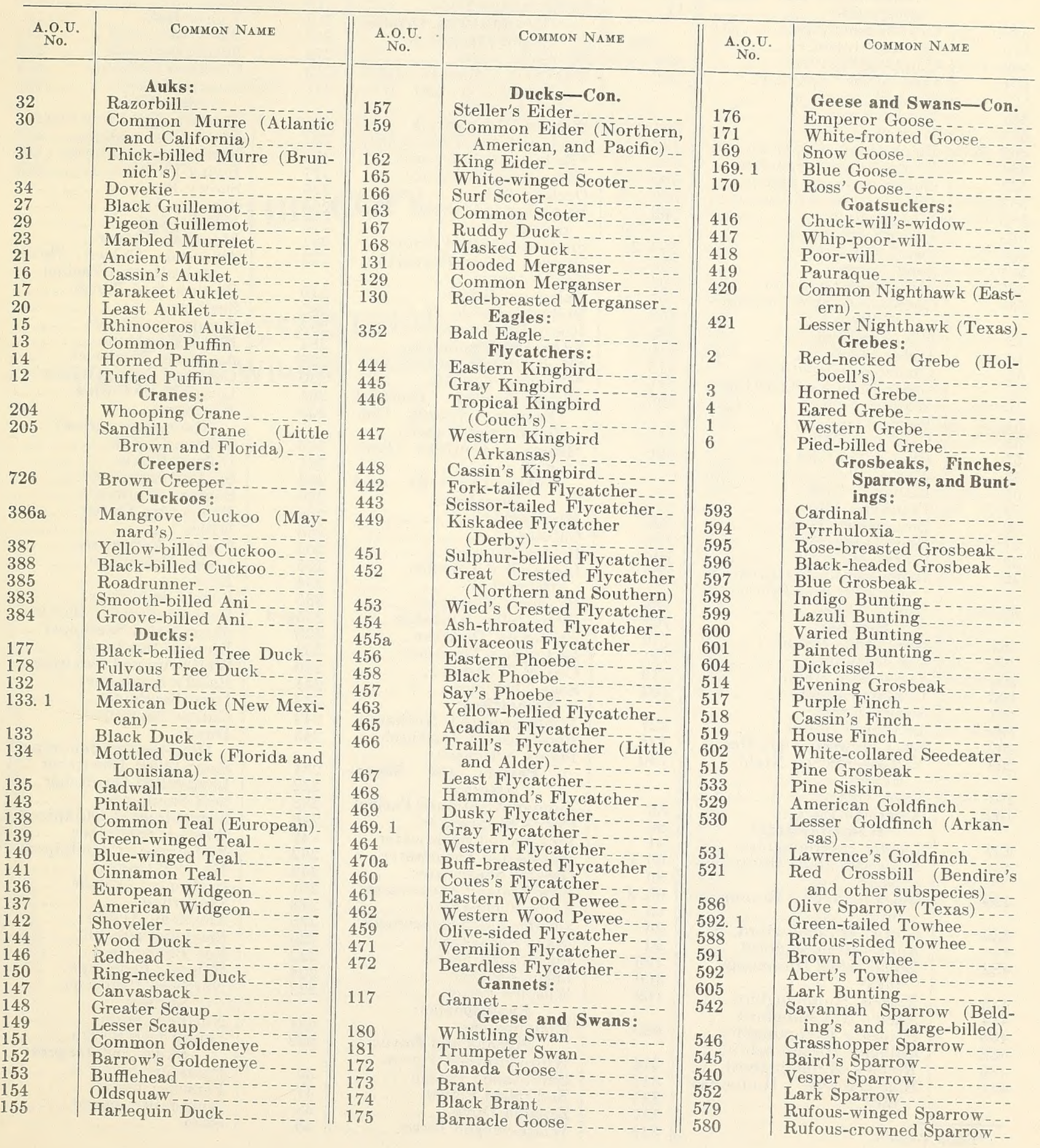




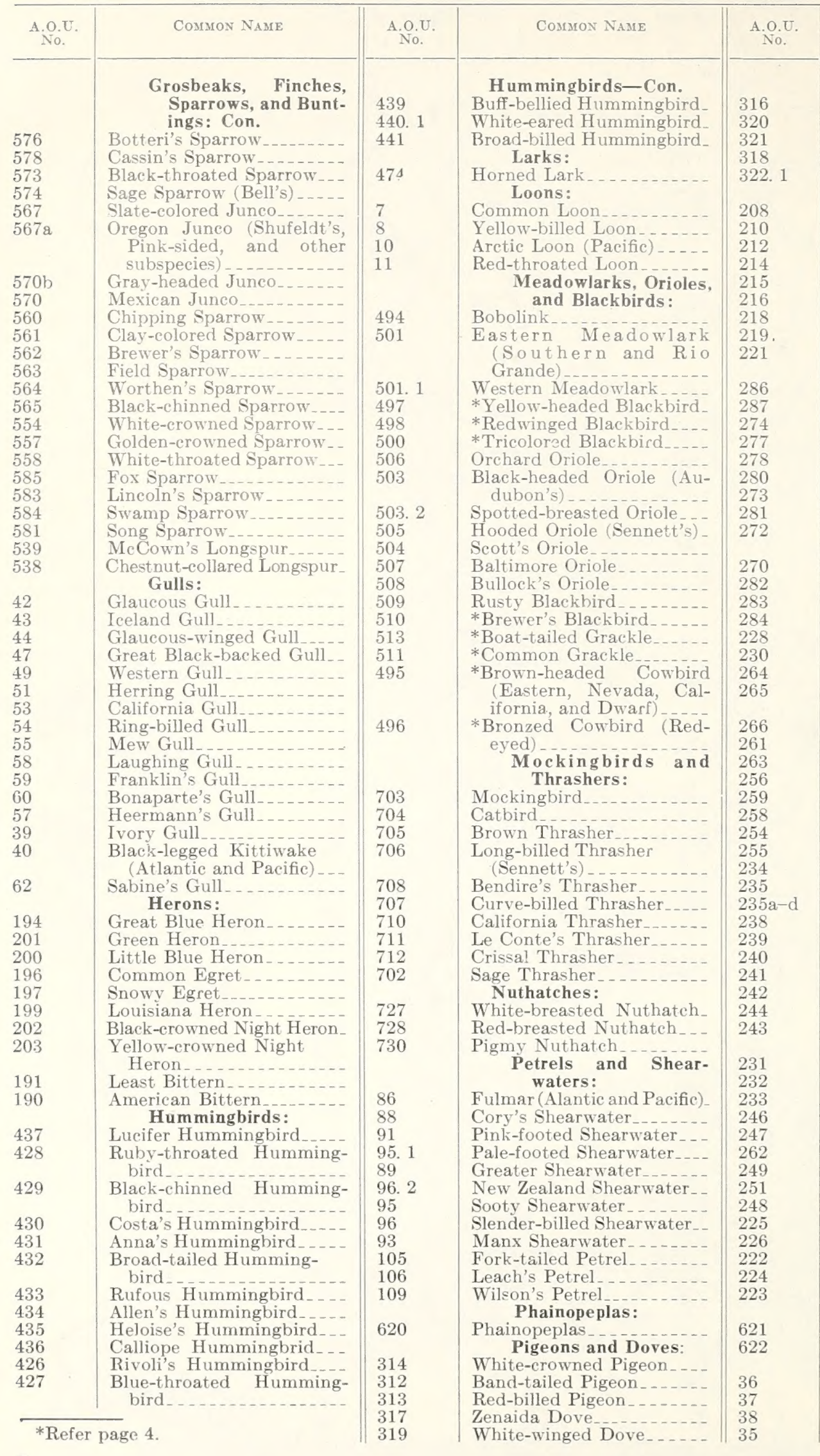

Pigeons and Doves-Con.

Mourning Dove

Ground Dove -

Inca Dove.

White-fronted Dove--

Ruddv Quail-dove

Rails and Gallinules:

King Rail

Clapper Rail

Virginia Rail

Sora.

Yellow Rail

Black Rail

Purple Gallinule

Common Gallinule.......

American Coot

Shorebirds:

American Oystercatcher...

Black Oystereatcher.

Semipalmated Plover.....

Piping Plover

Wilson's Plover

Killdeer

Mountain Plover

American Golden Plover (Atlantic and Pacific)

Black-bellied Plover _......

Surfbird

Ruddy Turnstone

Black Turnstone

American Woodcock.

Common Snipe (Wilson's)

Long-billed Curlew.......

Whimbrel

(Hudsonian curlew)

Eskimo Curlew

Upland Plover

Spotted Sandpiper

Solitary Sandpiper

Willet

Greater Yellowlegs

Lesser Yellowlegs.

Knot.

Purple Sandpiper

Rock Sandpiper (Aleutian)

Sharp-tailed Sandpiper.

Pectoral Sandpiper

White-rumped Sandpiper.

Baird's Sandpiper

Least Sandpiper.

Curlew Sandpiper --------

Dunlin

(Red-backed Sandpiper)

Short-billed Dowitcher

Long-hilled Dowitcher...

Stilt Sandpiper

Semipalmated Sandpiper.

Western Sandpiper

Buff-breasted Sandpiper...

Marbled Godwit.

Hudsonian Godwit - -

Sanderling

American Avocet

Red Phalarope

Wilson's Phalarope

Northern Phalarope

$$
\text { Shrikes: }
$$

Northern Shrike_.

Loggerhead Shrike

Skuas and Jaegers:

Pomarine Jaeger.

Parasitic Jaeger.

Long-tailed Jaeger

Skua 


\begin{tabular}{|c|c|c|c|c|c|}
\hline $\begin{array}{l}\text { A.O.U. } \\
\text { No. }\end{array}$ & Common Name & & Common Name & & Common Name \\
\hline $\begin{array}{l}615 \\
614 \\
616 \\
617 \\
613 \\
612 \\
612.1 \\
611 \\
611.2 \\
422 \\
423 \\
424 \\
425 \\
607 \\
608 \\
609 \\
610\end{array}$ & 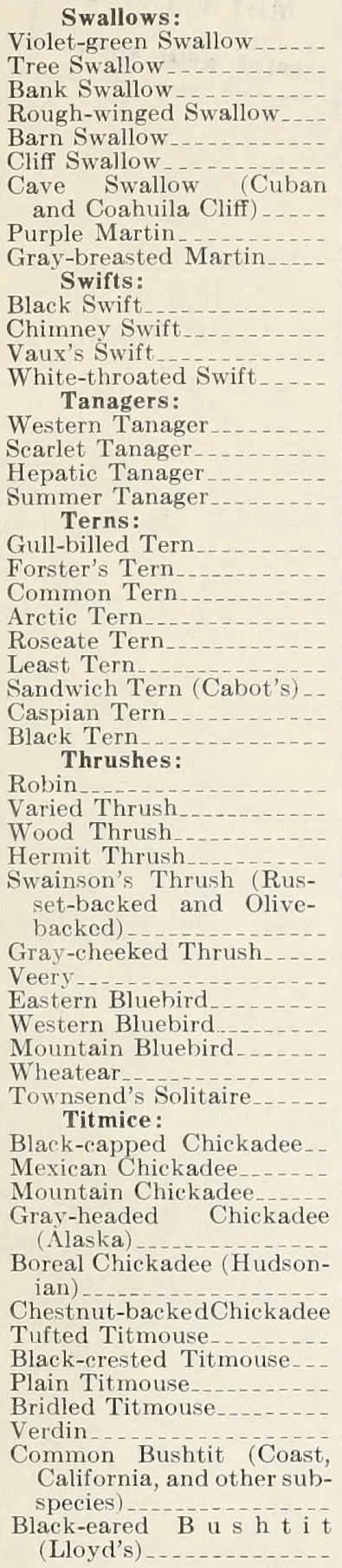 & 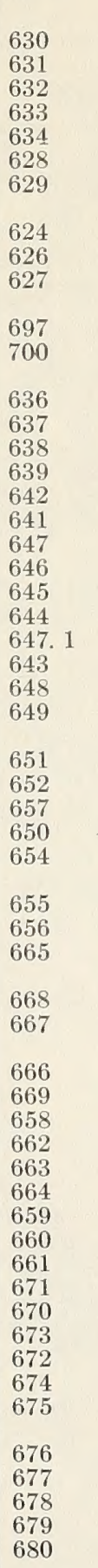 & 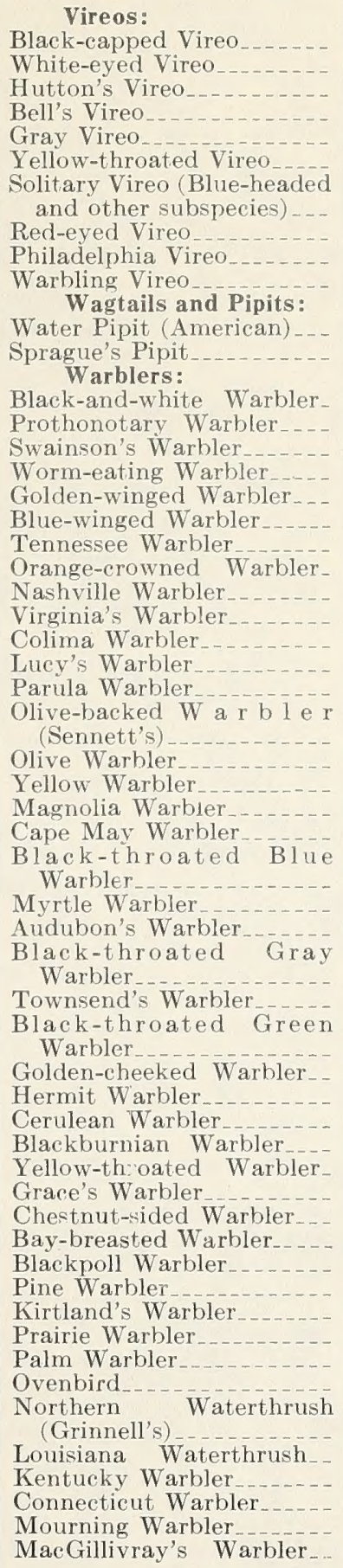 & 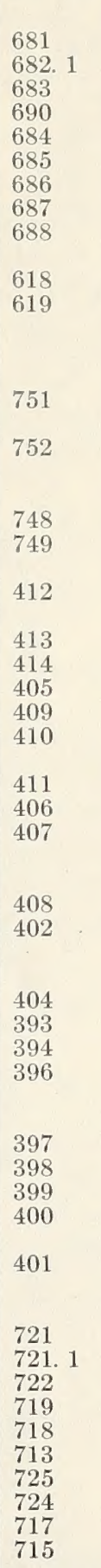 & 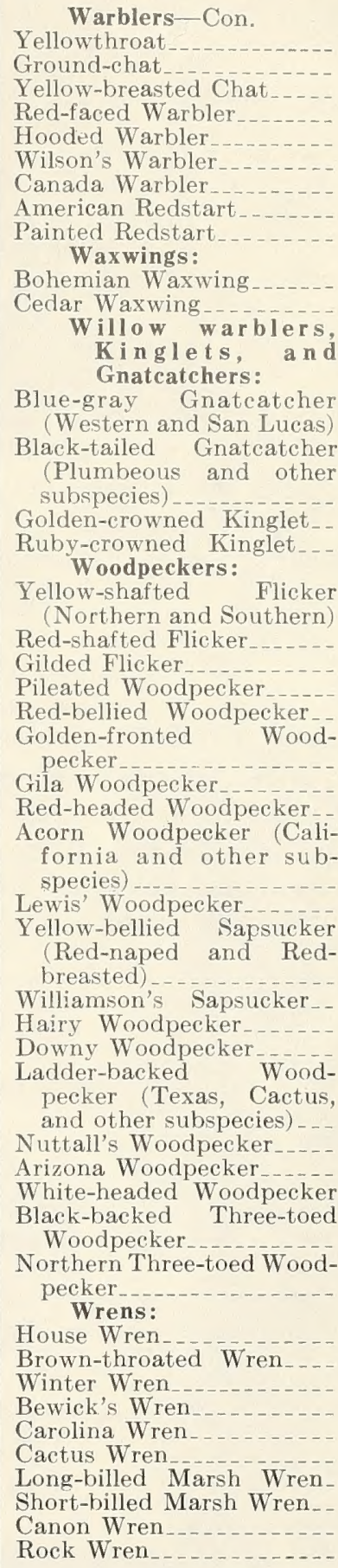 \\
\hline
\end{tabular}


*CONTROL OF DEPREDATING BIRDS-Authority: $\$ \S 10.61$ to 10.65 of Title 50, CFR, issued under sec. 3, 40 Stat. 755, as amended; 16 U.S.C. 704. Interpret or apply E.O. 10250, 16 F.R. 5385, 3 CFR, 1951 Supp.

$\S 10.62$ Depredating blackbirds, cowbirds and grackles.

Any person without a permit, may kill yellow-headed, red-winged, bi-colored red-winged, tricolored red-winged, and Brewer's Blackbirds, cowbirds, and all grackles under the conditions and restrictions prescribed in this section when found committing or about to commit serious depredations upon any agricultural crop or ornamental or shade trees.

(a) No birds killed pursuant to this section nor the plumage of such birds shall be sold or offered for sale.

(b) Every person availing himself of the privileges of this section shall permit at all reasonable times, and particularly during any operations thereunder, any Federal or State game or deputy game agent, warden, protector, or other game law enforcement officer free and unrestricted access to the premises on which such operations have been or are being conducted and shall furnish promptly to such officer whatever information regarding said operations the officer may require.

(c) Nothing in this section shall be deemed to permit the killing of any of the aforesaid birds in violation of any State law or regulation, and if a State permit to kill the birds is required, such permit must be procured before the privileges conferred by this section are exercised. (50 CFR 10.62).

Some common birds which are not afforded protection by Federal law:

$\begin{aligned} \text { Ibises } & \text { Crows, ravens, jays } \\ \text { Pelicans } & \text { Starlings } \\ \text { Cormorants } & \text { English sparrows } \\ \text { Anhingas } & \text { Golden eagle, all hawks and owls }\end{aligned}$

Wildlife Leaflet 432, May 1961. (Supersedes WL 327, May 1950.) 